\title{
Influence of Family Structure on Consumer Decision-making Style in Iran
}

\author{
Kambiz Heidarzadeh Hanzaee \\ Associate Professor Marketing \\ Department of Business Management, Science and Research Branch, Islamic Azad University \\ Ashrafee-e-Esfahani Highway, Hesarak Road, Zip code: 1477893855, Tehran, Iran \\ Tel: 98-21-4486-9667Ｅ-mail: heidarzadeh@srbiau.ac.ir \\ Fereshteh Lotfizadeh, Ph.D (Corresponding author) \\ Department of Business Management, Science and Research Branch, Islamic Azad University \\ Second floor, 20 No, Shahid Seyyedi Alley, North Boulevard Street \\ Zip code: 3413966674, Qazvin, Iran \\ Tel: 98-912-381-5385Ｅ-mail: Lotfizadeh1981@gmail.com
}

Received: January 29, 2011

Accepted: June 22, $2011 \quad$ Published: November 1, 2011

doi:10.5539/ijbm.v6n11p297

URL: http://dx.doi.org/10.5539/ijbm.v6n11p297

\begin{abstract}
Purpose- The purpose of this conceptual paper is to attempt to demonstrate the impact of marital roles and family structure on consumer decision-making style within an Islamic culture.

Design/methodology/approach- This paper wants to understand how husbands/wives with Eastern norms and Islamic culture use different decision-making style. Reviews of literature in consumer decision-making and family structure served for the development of the conceptual arguments. This article utilizes the library and secondary data from World Bank Group (2006) and Statistical Center of Iran (2007) for analysis.

Findings-Family structure (that is male-dominate, wife-dominate, joint decision-making or egalitarianism style) and also Islamic norms and Iranian culture have profound impact on decision-making style on Iranian families.

Research limitations/implications- Since the paper presents only the conceptual framework and secondary data, it does not include empirical research that could be carried out to validate the arguments presented in this paper. Children have incredible influence on family decision-making styles. But this paper does not address these effects.

Practical Implication- It is believed that male and female consumers in Iran may also have certain distinctive characteristics in terms of their decision orientation towards shopping and buying that could be of equal interest to both researchers and marketing practitioners.

Originality/Value- Current Islamic research is limited to Halal and Islamic finance, and little investigation has been done on Muslims' consumer behavior. So this conceptual paper reveals that family structure can influence on a wife or husband's decision-making style.

Keywords: Consumer decision-making style, Segmentation, Family structure, Muslim, Iran

\section{Introduction}

The consumers' behavior when choosing between alternative products is one of the most analyzed topics in consumer interest studies. However, although many factors influence consumer decision-making, consumers are thought to approach the market with certain basic decision-making styles.

Decision-making is becoming increasingly complex for consumers and with the emergence of electronic forms of product display and information, the complexity of decision-making intensifies further. The advent of global markets has resulted in a plethora of product choices, retail channels and promotional activity, which make consumers' decision-making increasingly complex. In the extensive consumer behavior literature, most studies assume that all consumers approach shopping with certain decision-making traits that combine to form a consumer's decision-making style (Walsh et al., 2001b). Decision-making styles are important to marketing because they determine consumer behavior, are relatively stable over time and are relevant for market segmentation. In the past two decades, global marketers have been attempting to explore various market opportunities in Asia, with particular focus on the Muslim market.

From a methodological perspective, effective market segmentation requires meaningful bases or variables with which the total market can be divided. Consumer markets are typically divided by demographic, psychographic or buying-related variables. A demographic segmentation can be conducted easily, because popularity of
\end{abstract}


demographic segmentation is the possible correlation between demographic characteristics and specialized consumer activities such as shopping and buying. Products such as clothing and personal care are designed, targeted and promoted with either men or women in mind. Another reason for the popularity of demographic segmentation is that demographics are usually well defined, and above all, are amongst the easiest to measure (Pol, 1991).

Several demographic variables may be used to segment consumer markets. Among those commonly used by marketers are income, age, gender, ethnicity, marital status and household size. Among these variables, gender has been and continues to be one of the most popular forms of market segmentation for a significant proportion of products and services.

Researchers found that family is the most influential unit in consumer behavior. Family members have a growing effect on each other's in decision-making. Based on demographic segmentation within the family, a husband and wife have different needs, wants, motivation and behaviors. This paper is related to the differences between husbands and wives in the area of consumer decision-making style. In order to broaden understanding of role differentiation in family economic decisions, this article also addresses two related questions:

1. Do marital roles in consumer decision-making differ by family member (wife/husband)?

2. Do husbands' and wives' decision-making roles differ in Islamic countries?

Answers to these questions will be useful to a large number of researchers sharing an interest in consumer behavior in Islamic countries. Marketing researchers continue to explore alternative bases for segmenting markets. Information about the roles played by husbands and wives can be useful for marketing researchers to use in addition to sex roles as a basis for market segmentation.

\section{Muslim Consumers in Iran}

Muslims constitute $20 \%$ of the world population and actively participate in the global economy as investors, suppliers, manufacturers, bankers, and traders. Muslim consumers represent one of the fastest growing consumer segments. However, despite its increasing significance, the intersection between Islam and marketing theory and practice remains largely understudied and poorly understood. This paper aims to provide relevant theoretical background and to present the results of the latest empirical research in the domain of consumer decision-making styles. This study represents an initial step in analyzing the effect of marital roles on consumer decision-making styles as it may be perceived by the customers of Islamic Republic of Iran. Worldwide, social changes have caused significant shifts in countries. For example, during one decade in Iran, some changes have occurred that you can see in the Table 1.

Fischer and Arnold (1994) noted that social changes, such as the increasing numbers of women in paid work force, may eventually reduce or eliminate some of these sex differences in shopping behavior.

Women in Iran have rapidly come to represent one of the most lucrative market segments and this population shows a positive indication in recent decades. In 1991, 6.7 million members of the Iranian population were below the age of 14 years, while another 3.5 million were in the age group 15-24 years. It has been estimated that the population in the age group 15-24 years has increased, from 3.97 million in 1995 to 4.45 million in the year 2000 and to 17.7 million in 2006 .

Yet, as the standard of living among Iranians has improved significantly, further stimulated by changing lifestyles, women today are granted greater freedom to make their own shopping and consumption decisions. As a result, female buying power has increased rapidly as more women enter the marketplace. This is not surprising when considering that shopping has become one of the important activities in spousal Iranians. Hence, with an expanding young spousal population and the strong marketing impact that they have created, marketers and consumer researchers have become increasingly interested in exploring spouses' the shopping approaches and decision-making.

The World Bank Group (2006) identified Iran as the country with the world's second-largest population after Egypt. Nearly three-quarters of Iran's population is under the age of 30. According to the Iranian national statistics website, of the 70 million Iranian citizens, $50.9 \%$ are male and $49.1 \%$ are female. Of this total, $71 \%$ live in urban areas and $29 \%$ reside in rural regions. Most of the country's population is young, with increasing hopes and expectations for a better future. About $62 \%(43,786,731)$ of the total population $(70,495,782)$ is under the age of 30 , with $40 \%$ between 10 and 25 years of age. These data are shown in the Table 2.

Given that Iran is one of the world's largest Muslim consumer markets and is considered by many to be a world economic champion, there are some questions for marketers and advertisers, for instance, who within the Iranian family influences the family's purchase decision-making process and who within the Iranian family makes the final purchase decision? Such questions are fundamental to a more thorough and complete understanding of family purchase decision-making within the Iranian family.

\section{Family Structure}

Given that the number of family household units is significantly greater than the number of single households, research in the area of family decision-making is important in advancing our knowledge of consumer behavior (Qualls, 1987).

The literature on marital roles in family consumption behavior reveals an interesting trend away from highly simplified notions of role differentiation in decision-making (Davis \& Rigaux, 1974). 
Research in the area of household decision behavior has primarily focused upon three critical issues:

(1) which family member makes the decision,

(2) out-comes of household decision behavior, and

(3) factors that determine which family member makes the decision (Qualls, 1987).

As a whole, results of the research on household decision behavior suggest that changes are taking place in the attitudes and behavioral orientation of men and women in today's household. These changes, which have altered the composition and decision role structure of the traditional household unit, have been attributed to various causes, including changing cultural norms, increases in the number of working wives, delayed first marriages, and shifting societal standards (Qualls, 1987).

The commonly accepted role structure of family purchase decision-making is (1) husband-dominated decisions, (2) wife-dominated decisions, (3) autonomic decisions (in which either the husband or wife is the primary or sole decision maker, but not both), and (4) syncratic or joint decisions (in which both are influential) (Xia et al., 2006). The process of joint decision-making by husbands and wives is of considerable interest both to sociologists and psychologists and to marketing and advertising strategists. Psychologists and sociologists are concerned with the roles played by husbands and wives in joint decision-making and the dependence of these roles on various psychological and socioeconomic factors (Radner, 1962; Strodtbeck, 1951). Marketing and advertising researchers are concerned with determining which spouse has the dominant influence in various types of decisions so that marketing and advertising strategy can be oriented accordingly (Davis, 1971).

Blood and Wolfe (1960) have contended that the degree of influence attributed to either the husband or wife in a family decision is a function of the level of traditional values existing in the family. For example, if the family is more oriented toward traditional marital-role values, the husband will be expected to make the majority of decisions and the wife's role will usually be limited to domestically oriented tasks (Qualls, 1987).

While it would be prudent to realize that some products will tend to be gender dominant (e.g. wife's clothes), typically a higher level of egalitarianism would be seen to predict more joint decisions, more wife-dominated decisions and fewer husband-dominated decisions (Ford et al., 1995; LaTour et al., 1993; Rodman, 1972).

One important social factor that has consistently been shown to be important is the role of egalitarianism in family purchase decision-making (Green et al., 1983). Egalitarianism is defined as a value system emphasizing equality in marital relations (Bott, 1957). Conversely, a higher level of egalitarianism would predict more joint decisions, more wife-dominated decisions, and fewer husband-dominated, decisions (LaTour et al., 1993).

Various mediating variables that may influence family decision-making have been examined by a number of researchers. For example, Hallenbeck (1966) looked at the relative influence of referent power in the marriage and its possible link to decision-making. Hill (1988) has examined the impact of stage of the family life cycle. Rogler and Procidano (1986) have explored the role of social networks. The work of Qualls and Jaffe (1992) delved into the role of possible conflict between spouses and the resulting impact on family decision-making. The works of Green et al. (1983) have pointed out the importance of examining the role of egalitarianism in family purchase decision-making.

\section{Consumer Decision-making Styles}

Decision-making is more complex and even more important for consumers today than in the past. Consumers are besieged by advertising, news articles, and direct mailings that provide an abundance of information, much of it with mixed messages. In addition, increases in the number and variety of goods, stores, and shopping malls, and the availability of multi-component products and electronic purchasing capabilities have broadened the sphere for consumer choice and have complicated decision-making (Hafstrom et al., 1992). Identifying basic characteristics of decision-making style is central to consumer-interest studies. This identification helps to profile an individual's consumer style, educate consumers about their specific decision-making characteristics, and counsel families on financial management (Sproles \& Kendall, 1986).

Sproles (1985) and Sproles and Kendall (1986) have been instrumental in developing and testing a Consumer Style Inventory (CSI), that could point a new direction in decision-making research.

Consumer decision-making style can be defined "as a mental orientation characterizing a consumer's approach to making choices" (Sproles \& Kendall, 1986, p. 267). Sproles and Kendall (1986) view this construct as "basic consumer personality", analogous to the concept of personality in psychology.

Research on this construct can be categorized into three main approaches: the consumer typology approach (Darden \& Ashton, 1974; Moschis 1976); the psychographics /lifestyle approach (Lastovicka, 1982); and the consumer characteristics approach (Sproles, 1985; Sproles \& Kendall, 1986; Sproles \& Sproles, 1990). The unifying theme among these three approaches is the tenet that all consumers engage in shopping with certain fundamental decision-making modes or styles including rational shopping, consciousness regarding brand, price and quality among others. Among these three approaches, however, the consumer characteristics approach seems to be the most powerful and explanatory since it focuses on the mental orientation of consumers in making decisions. As such, this approach deals with cognitive and affective orientations of consumers in their process of decision-making. It assumes that decision-making styles can be determined by identifying general orientations towards shopping and buying. This knowledge is also useful in terms of identifying segments or clusters of consumers sharing similar orientations to shopping (Lysonski et al., 1996). 
Sproles proposes that consumers adopt a "shopping personality" that is relatively enduring and predictable in much the same way as psychologists view personality in its broadest sense (Sproles, 1985).

Sproles and Kendall (1986) have refined this inventory and accordingly developed a more parsimonious scale consisting of 40 items. Their Consumer Style Inventory (CSI) consists of eight mental consumer style characteristics:

1) Perfectionistic, high-quality conscious consumer - a characteristic measuring the degree to which a consumer searches carefully and systematically for the best quality in products. They are searching for high quality, not good

2) Brand conscious, "price equals quality" consumer - measuring a consumer's orientation to buying the more expensive, well-known brands. They have positive attitudes toward department and specialty stores, where brand names and higher prices prevail. They also appear to prefer best-selling, advertised brands

3) Novelty-fashion conscious consumer - a characteristic identifying consumers who appear to like new and innovative products and gain excitement from seeking out new things

4) Recreational, hedonistic consumer - a characteristic measuring the degree to which a consumer finds shopping a pleasant activity and shops just for the fun of it

5) Price conscious, "value-for-money" consumer - a characteristic identifying those with particularly high consciousness of sale prices and lower prices in general. They are likely to be comparison shoppers

6) Impulsive, careless consumer - identifying those who tend to buy on the spur of the moment and appear unconcerned with how much they spend or getting "best buys". They have no plan for their shopping

7) Confused by overchoice consumer - a characteristic identifying those consumers who perceive too many brands and stores from which to choose. They experience information overload in the market and have difficulty making decisions.

8) Habitual, brand-loyal consumer - a characteristic indicating consumers who have favorite brands and stores, who have formed habits in choosing these repetitively.

The CSI has been applied to nine countries: the U.S., Korea, New Zealand, Greece, India, Iran, Malaysia, the United Kingdom, and China. There is evidence that decision-making styles can vary across cultures, but it is not known how they vary across all cultures.

Since its introduction, a series of investigations have been conducted aimed at testing the generalisability of the CSI within a single country (e.g. Korea: Hafstrom, Chae \& Chung, 1992; China: Fan \& Xiao, 1998; Hiu, Siu, Wang \& Chang, 2001; New Zealand: Durvasula, Lysonski \& Andrews, 1993; India: Canabal, 2001; Iran: Hanzaee \& Aghasibeig, 2008; Germany: Walsh, Mitchell \& Thurau, 2001; Walsh \& Vincent, 2001; UK: Mitchell \& Bates, 1998; South Africa: Radder, Li \& Pietersen, 2006; Turkey: Gonen \& Osmete, 2006; Kavas \& Yesilada, 2007; Malaysia: Wan Omar et al. 2009; Taiwan: Hou \& Lin, 2006; Brazil: Dos Santos \& Fernandes, 2006) as well as across different countries (e.g. USA, New Zealand, India and Greece: Lysonski, Durvasula \& Zotos, 1996; China and Macau: Ng, 2005; USA and Korea: Wickliffe, 2004). These studies confirm varying portions of the original CSI factors while none of them reproduced all eight completely.

For example, Durvasula et al. (1993) examined the cross-cultural generalizability of the instrument using a sample of New Zealand university students and found that the instrument was applicable even though some items loaded differently compared with the Sproles and Kendall (1986) original study. Hafstrom et al. (1992, p. 120) examined Korean university students and found that "there is reason for cautious optimism that the CSI has elements of construct validity and has potential use across international populations."

Few other studies have attempted to thoroughly explore the antecedents and consequences of consumer decision-making styles. McDonald (1993) investigated the roles of shopper decision-making styles in predicting consumer catalogue loyalty. Shim and Koh (1997) examined the effects of socialization agents and social-structural variables on adolescent consumer decision-making styles. Salleh (2000) analysed consumers' decision-making style dimensions across different product classes. Wesley, LeHew and Woodside (2006) explored how consumers' decision-making styles relate to their shopping mall behavior and their global evaluations of shopping malls. Cowart and Goldsmith (2007) investigated the influence of consumer decision-making styles on online apparel consumption by college students. More recently, Kwan, Yeung and Au (2008) explored the effects of lifestyle characteristics on consumer decision-making styles of young fashion consumers in China. Hanzaee and Ahasibeig (2008) investigated differentiation in consumer decision-making style in generation Y males and females in Iran. Mokhlis and Salleh (2009) examined the role of gender differentiation in consumer decision-making styles in Malaysia.

\section{Gender and Consumer Decision-making Style}

Studies have reported gender differences in consumers' decision-making styles. Bakewell and Mitchell (2003) examined the decision-making styles of adult female Generation Y consumers in the UK. In their later study on decision-making styles of male consumers in the UK (Bakewell \& Mitchell, 2004), all of the original eight traits plus four new traits were identified. Their study also demonstrated the potential of the CSI for segmenting markets as meaningful and distinct groups of male consumers with different decision-making styles. 
Mitchell and Walsh (2004) compared the decision-making styles of male and female shoppers in Germany. The researchers confirmed the construct validity of all eight CSI factors for female shoppers and four of the factors for male shoppers. Bakewell and Mitchell (2006) undertook a similar study in the UK. Using a sample of 480 male and female undergraduate students, they found that nine decision-making styles were common to both genders. In addition, three new male traits and three new female traits were also identified in their study.

A recent study conducted by Hanzaee and Aghasibeig (2008) in an Iranian setting also indicated that Generation Y male and female consumers differ in their decision-making styles. However, of the 10-factor solution confirmed for males and 11-factor solution for females, nine factors were found to be common to both genders. The authors regarded this similarity as a result of the changing gender roles in modern Iran.

\section{Discussion \& Deliberation}

Islamic marketing combines the principle of value maximization with the principles of equity and justice for the welfare of society. The vast majority of research on family decision-making has used Western respondents. Eastern cultures have received less attention, although significant economic and social changes have occurred in the Asia region, which make this region more modernized or "Westernized." A number of differences in family purchase decision-making can still be anticipated, as compared to the Western families. Although Iran has been successful in its social as well as economic developments, its unique social environment, different cultural values, traditions, and norms tend to create different spousal attitudes and behaviors in the family purchase decision-making process.

Research on family purchase decision-making can help further marketers' knowledge of how family households make decisions. A better knowledge of spousal influence patterns and purchase-decision processes, in particular, can enable marketers to develop effective marketing segmentation strategies (Davis \& Rigaux, 1974) as well as communication strategies and programs (Su et al., 2003). Thus examining decision-making styles within the family would be very crucial for researchers in the Muslim market. Moreover, Muslims have specific rules and ceremonies, such as praying in mosques, eating only Halal foods and wearing specific dresses. These must be included in the criteria for this segment. Overall, all available segmentation criteria have weaknesses and an ideal method of market segmentation is not achievable. Additional criteria will probably not lead to better market segmentation, but one way to increase the quality of market segmentation could be to develop a multistage segmentation approach. By doing sub segments based on the different criteria, it becomes possible to get a more refined picture of Muslim consumer preferences and a better understanding of which segments exist. This approach enhances the development of products that better fit the varying preferences of Muslim customers.

Moreover, because gender has been identified in much literature on consumer shopping behavior as a significant factor in understanding consumer behavior and as a fundamental market segmentation index for companies to meet their customers' needs and wants, marketers should strive to understand the gender differences in decision-making styles. Research addressing the issue of gender differences in decision-making styles could help marketers to find better ways of communicating with both sexes and to guide marketing mix decisions (Mitchell \& Walsh, 2004). In Iran Hanzaee and Aghasibeig (2008) demonstrated that male and female consumers differ in their decision-making style.

In Iran, eastern culture and Islam religious beliefs dominate in families, so wives and husbands have different decision-making styles. Now, after social changes, some families are traditional, while others are modern.

Based on these categories, traditional and modern families have different decision-making style and these differentiations may occur in product type, time or place of purchase, money spent or family decision maker.

Consequently, in families with husband- dominated, wife-dominated or egalitarianism styles, the wife and husband have divergent decision-making style. On the other hand, family structure as a social-structural variable can influence the decision-making styles of family members and relate to their purchase behavior.

If consumers' decision-making styles vary among countries, advertising and other elements of the marketing mix must be adjusted to accommodate these differences. For example, if there is a large segment of impulsive buyers in a specific country, advertising appeals may be formulated with this in mind. Thus, most of the empirical research on decision-making styles should have focused on Muslim consumers, especially in family members on Muslim countries.

In conclusion, prior studies provide convincing evidence that consumers' decision-making styles vary by genders. Meanwhile, none of these studies has focused on the effect of marital roles on consumer decision-making styles. It is believed that male and female consumers in Iran may also have certain distinctive characteristics in terms of their decision orientation toward shopping and buying that could be of equal interest to both researchers and marketing practitioners. This study fills this gap by studying the differences in decision-making styles based on marital roles in the Iranian context.

This paper ignores children's impact on family decision-making style. After economical, social and cultural changes in Asia, this segment has authority for decision-making in the family. Therefore, research on children's influence on family decision-making and children's decision-making styles in Muslim countries could be useful and applicable for marketers and advertisers. 


\section{References}

Bakewell, C., \& Mitchell, V. W. (2006). Male versus female consumer decision-making. Journal of Business Research, 59, 1297-1300. http://dx.doi.org/10.1016/j.jbusres.2006.09.008

Bakewell, C., \& Mitchell, V. W. (2004). Male consumer decision-making styles. International Review of Retail, Distribution and Consumer Research, 14 (2), 223-240. http://dx.doi.org/10.1080/0959396042000178205

Bakewell, C., \& Mitchell, V. W. (2003). Generation Y female consumer decision-making styles. International Journal of Retail \& Distribution Management, 31 (2), 95-106. http://dx.doi.org/10.1108/09590550310461994

Blood, R. D., \& Wolfe, D. M. (1960). Husbands and wives. New York: The Free Press.

Boot, E. (1957). Family and social network. New York: The Free Press.

Canabal, M. E. (2001). Decision-making styles of young South Indian consumers: An exploratory study. College Student Journal, 36 (1), 12-19.

Cowart, K. O., \& Goldsmith, R. E. (2007). The influence of consumer decision-making styles on online apparel consumption by college students. International Journal of Consumer Studies, 31 (6), 639-647. http://dx.doi.org/10.1111/j.1470-6431.2007.00615.x

Darden, W.R., \& Ashton, D. (1974). Psychographic profiles of patronage preference groups. Journal of Retailing, 50 (Winter), 99-112.

Davis, H.L., \& Rigaux, B.P. (1974). Perception of marital roles in decision processes. Journal of Consumer Research, 1 (June), 51-62. http://dx.doi.org/10.1086/208581

Davis, H.L. (1971). Measurement of husband-wife influence in consumer purchase decisions. Journal of Marketing Research, 8, 305-312. http://dx.doi.org/10.2307/3149567

Dos Santos, C. P., \& Fernandes, D. V. D. H. (2006). Evaluation of the Consumer Style Inventory (CSI) scale in the Brazilian Context. Revista de Administracao Mackenzie, 7 (2), 11 - 38.

Durvasula, S., Lysonski, S., \& Andrews, J. C. (1993). Cross-Cultural Generalizability of a Scale for Profiling Consumers' Decision-Making Styles. Journal of Consumer Affairs, 27 (1), 55-65. http://dx.doi.org/10.1111/j.1745-6606.1993.tb00737.x

Fan, J. X., \& Xio, J. J. (1998). Consumer decision-making styles of young-adult Chinese. Journal of Consumer Affairs, 32 (2), 275-294. http://dx.doi.org/10.1111/j.1745-6606.1998.tb00410.x

Fischer, E., \& Arnold, S.J. (1994). Sex, Gender Identity, Gender Role Attitudes, and Consumer Behavior. Psychology \& Marketing, (March/April), 163-82. http://dx.doi.org/10.1002/mar.4220110206

Ford, J.B., LaTour, M.S., and Henthorne, T.L. (1995). Perception of marital roles in purchase decision processes: a cross-cultural study. Journal of the Academy of Marketing Science, 23 (2), 120-31. http://dx.doi.org/10.1177/0092070395232004

Gonen, E., \& Osemete, E. (2006). Decision-making styles of young Turkish consumers. Journal of the Home Economics Institute of Australia, 13 (1), 26-33.

Green, R.T., Jean-Paul, L. Jean-Louis, C. Cunningham, I.C.M. Verhage, B., and Strazzieri, A. (1983). Societal development and family purchasing roles: a cross-national study. Journal of Consumer Research, 9 (March), 436-42. http://dx.doi.org/10.1086/208937

Hafstrom, J. L., Chae, L. S., \& Chung, Y. S. (1992). Consumer decision-making styles: Comparison between United States and Korean young consumers. Journal of Consumer Affairs, 26 (1), 146-158. http://dx.doi.org/10.1111/j.1745-6606.1992.tb00020.x

Hallenbeck, P.N. (1966). An Analysis of Power Dynamics in Marriage. Journal of Marriage and the Family, 28, 200-3. http://dx.doi.org/10.2307/349283

Hanzaee, K. H., \& Aghasibeig, S. (2008). Generation Y female and male decision-making styles in Iran: Are they different?. International Review of Retail, Distribution and Consumer Research, 18 (5), $521-537$. http://dx.doi.org/10.1080/09593960802573443

Hill, M.D. (1988). Class, kinship density, and conjugal role segregation. Journal of Marriage and the Family, 50 (August), 731-41. http://dx.doi.org/10.2307/352642

Hiu, A. S. Y., Siu, N. Y. M., Wang, C. C. L., \& Chang, L. M. K. (2001). An investigation of decision-making styles of consumers in China. Journal of Consumer Affairs, 35 (2), 326-345. http://dx.doi.org/10.1111/j.1745-6606.2001.tb00117.x

Hou, S. C., \& Lin, Z. H. (2006). Shopping styles of working Taiwanese female. Proceedings, International Conference on Business and Information, Singapore, 12-14 July 2006.

Kavas, A. Yesilada, F. (2007). Decision-making styles of young Turkish consumers. European Journal of Economics, Finance and Administrative Sciences, 9, 73-85.

Kwan, C. W., Yeung, K. W., \& Au, K. F. (2008). Relationships between consumer decision-making styles and lifestyle characteristics: Young fashion consumers in China. Journal of the Textile Institute, 99 (3), $193-209$. http://dx.doi.org/10.1080/00405000701462351 
Lastovicka, J.L. (1982). On the validation of lifestyle traits: a review and illustration. Journal of Marketing Research, 19 (February), 126-38. http://dx.doi.org/10.2307/3151537

LaTour, M.S., Henthorne, T.L., and Ford, J.B. (1993). Perception of marital roles in purchase decision processes: a study of 100 Beijing couples. Asian Journal of Marketing, December, 45-60.

Lysonski, S., Durvasula, S., \& Zotos, Y. (1996). Consumer decision-making styles: A multi-country investigation. European Journal of Marketing, 30 (12), 10-21. http://dx.doi.org/10.1108/03090569610153273

McDonald, W. J. (1993). The roles of demographics, purchase histories and shopper decision-making styles in predicting consumer catalogue loyalty. Journal of Direct Marketing, 7 (3), 55-65. http://dx.doi.org/10.1002/dir.4000070308

Mitchell, V., \& Walsh, G. (2004). Gender Differences in German Consumer Decision-Making Styles. Journal of Consumer Behavior, 3 (4), 331-346. http://dx.doi.org/10.1002/cb.146

Mitchell, V., \& W. Bates, L. (1998). UK consumer decision-making styles. Journal of Marketing Management, 14, 199-225. http://dx.doi.org/10.1362/026725798784959345

Mokhlis, S., \& Salleh. H. S. (2009). Consumer Decision-Making Styles in Malaysia: An Exploratory Study of Gender Differences. European Journal of Social Sciences, 10 (4), 574-584.

Moschis, G.P. (1976). Shopping orientations and consumer uses of information. Journal of Retailing, 52 (Summer), 61-70, 93.

Ng, S. W. (2005). Shopping and buying decision on consumers' decision-making styles: A cross-cultural study of the youth Chinese and Macanese", In L. C. Huff \& S. M. Smith (Eds.), Conference Proceedings, Eleventh Cross-Cultural Research Conference, Puerto Rico, USA, 11-14 December 2005.

Pol, L. G. (1991). Demographic contributions to marketing: An assessment. Journal of the Academy of Marketing Science, 19 (1), 53-59. http://dx.doi.org/10.1007/BF02723424

Qualls, W.J. (1987). Household decision behavior: the impact of husbands' and wives' sex role orientation. Journal of Consumer Research, 14 (2), 264-79. http://dx.doi.org/10.1086/209111

Qualls, W.J., and Jaffe, F. (1992). Measuring conflict in household decision-making: read my lips and read my mind. Journal of Consumer Research, 19, 522-31.

Radder, L., Li, Y., \& Pietersen, J. J. (2006). Decision-making styles of young Chinese, Motswana and Caucasian consumers in South Africa: An exploratory study. Journal of Family Ecology and Consumer Science, 34, 20-31.

Radner, R. (1962). Team Decision Problems. Annals of Mathematical Statistics, 33, 857-81. http://dx.doi.org/10.1214/aoms/1177704455

Rodman, H. (1972). Marital Power and the Theory of Resources in a Cross-Cultural Context. Journal of Comparative Family Studies, 1, 50-61.

Rogler, L.H., \& Procidano, M.E. (1986). The effect of social networks on marital roles: a test of the Bott hypothesis in an intergenerational context. Journal of Marriage and the Family, 48, 693-701. http://dx.doi.org/10.2307/352562

Rogler, L.H., \& Procidano, M.E. (1989). Egalitarian spouse relations and wives' marital satisfaction in intergenerationally linked Puerto Rican families. Journal of Marriage and the Family, 51 (February), 37-9. http://dx.doi.org/10.2307/352366

Salleh, R. (2000). The analysis of consumers' decision-making styles dimensions across different product classes. Unpublished doctoral dissertation. University of Strathclyde, Glasgow, UK.

Shim, S., \& Koh, A. (1997). Profiling adolescent consumer decision-making styles: Effects of socialization agents and social-structural variables. Clothing and Textiles Research Journal, 15 (1), 50-59.

Sproles, E.K., \& Sproles, G.B. (1990). Consumer decision-making styles as a function of individual learning styles. The Journal of Consumer Affairs, 24 (Summer), 134-47. http://dx.doi.org/10.1111/j.1745-6606.1990.tb00262.x

Sproles G. B., \& Kendall, E. L. (1986 ). A methodology for profiling consumers' decision-making styles. Journal of Consumer Affairs, 20 (2), 267-279. http://dx.doi.org/10.1111/j.1745-6606.1986.tb00382.x

Sproles, G. B. (1985). From perfectionism to fadism: Measuring consumers' decision-making styles. Proceedings, American Council on Consumer Interests, 79-85.

Statistical Center of Iran. (2007). Vice Presidency for strategic planning and Supervision. [Online] Available: http://www.amar.org.ir/default.aspx?tabid $1 / 452$ (9 January 2011).

Strodtbeck, F.L. (1951). Husband-Wife Interaction Over Revealed Differences. American Sociological Review. 16, 468-73. http://dx.doi.org/10.2307/2088277

Su, C., Fern, E.F., and Ye, K. (2003). A Temporal Dynamic Model of Spousal Family Purchase Decision Behavior. Journal of Marketing Research, 11 (August), 268-81. http://dx.doi.org/10.1509/jmkr.40.3.268.19234

Xia, Y., Ahmed, Z.U., Ghingold, M., Hwa, N.K., Li, T.W., \& Ying, W.T.C. (2006 ). Spousal influence in Singaporean family purchase decision-making process. Asia Pacific Journal of Marketing and Logistics. 18 (3), 201-222. http://dx.doi.org/10.1108/13555850610675661 
Walsh, G., Mitchell, V. W., \& Thurau, T. H. (2001b). German Consumer Decision-making Styles. Journal of Consumer Affairs, 35 (1), 73-95. http://dx.doi.org/10.1111/j.1745-6606.2001.tb00103.x

Walsh, G., Thurau, T. H., Mitchell, V. W., \& Wiedmann, K.P. (2001a). Consumer Decision-making Style as a basis for Market Segmentation. Journal of Targeting, Measurement and Analysis for Marketing, 10 (2), 117-131. http://dx.doi.org/10.1057/palgrave.jt.5740039

Walsh, G., \& Vincent, W. (2001). German market mavens' decision-making styles. Journal of Euro-Marketing, 10 (4), 83-108. http://dx.doi.org/10.1300/J037v10n04_05

Wan Omar, M., Mohd Ali, M. N., Hussin, Z., \& Abdul Rahim, H. (2009). Decision orientations towards shopping and buying among young-adult Malays in the universities. International Journal of Business and Management, 4 (7), 26-30.

Wesley, S., LeHew, W., \& Woodside, A. G. (2006). Consumer decision-making styles and mall shopping behavior: Building theory using exploratory data analysis and the comparative method. Journal of Business Research, 59 (5), 535-548. http://dx.doi.org/10.1016/j.jbusres.2006.01.005

Wickliffe, V. P. (2004). Refinement and Re-Assessment of the Consumer Decision-Making Style Instrument. Journal of Retailing and Consumer Services, 11 (1), 9-17. http://dx.doi.org/10.1016/S0969-6989(02)00057-7

World Bank Group. (2006). Iran country brief, The World Bank Group. [Online] Available: http://web. worldbank.org/ (9 January 2011).

Table 1. Age in first marriage in Iran (Statistical Center of Iran, 2007)

\begin{tabular}{|c|c|c|}
\hline \multicolumn{2}{|c|}{ Age in First Marriage } \\
\hline Female & Male & Year \\
\hline $22 / 4$ & $25 / 6$ & 1996 \\
\hline $23 / 2$ & $26 / 2$ & 2006 \\
\hline
\end{tabular}

Table 2. Number of males and females in Iran (Statistical Center of Iran, 2007)

\begin{tabular}{|c|c|c|c|}
\hline Female & Male & Male \& Female & Years Old \\
\hline $2,681,129$ & $2,823,485$ & $5,504,614$ & $11-14$ \\
\hline $8,783,431$ & $8,954,752$ & $17,738,183$ & $15-24$ \\
\hline $15,499,490$ & $15,919,889$ & $31,419,379$ & $25-64$ \\
\hline
\end{tabular}

